\title{
Using Learning Strategy of English for Young Learners to Create the Textbook of Gorontalo Language for Elementary School as an Effort to Maintain Gorontalo Cultures
}

\author{
Nurlaila Husain (Corresponding author) \\ Universitas Negeri Gorontalo \\ Kota Gorontalo, Gorontalo 96128, Indonesia \\ Indri Wirahmi Bay \\ Universitas Negeri Gorontalo \\ Kota Gorontalo, Gorontalo 96128, Indonesia
}

Rahmawaty Mamu

Universitas Negeri Gorontalo

Kota Gorontalo, Gorontalo 96128, Indonesia

Herson Kadir

Universitas Negeri Gorontalo

Kota Gorontalo, Gorontalo 96128, Indonesia

Received: December 3, 2018 Accepted: January 10, 2019 Published: January 24, 2019

doi:10.5296/ijld.v9i1.13990 URL: https://doi.org/10.5296/ijld.v9i1.13990

\begin{abstract}
Teaching Gorontalo language is one of the Gorontalo government efforts to maintain Gorontalo culture. It has been being taught in elementary schools for years and continuously becomes the government concern. In the previous research (Husain, Bay and Mamu, 2017), the
\end{abstract}


result of questionnaire generally indicated that the textbook used in teaching Gorontalo language was not colorful and attractive and the content was too monotonous. Additionally, certain teachers did not even use any textbook to teach and just tried to browse material on the internet. This research intends to create a textbook that will be used for teaching Gorontalo language in elementary schools based on the syllabus produced in the first year of research. Syllabus and textbook are created by adapting English for Young Learners (EYL) learning strategy. The content focuses on traditional musical instruments, traditional songs, traditional games and traditional dances and is introduced simply and nicely to the students as in EYL learning strategy. The students will have two benefits; they can learn Gorontalo language and its cultures at the same time. The research applies the Research and Development Method (Sugiyono, 2014, p. 297) to create the textbook of Gorontalo language with five main steps namely (1) creating the textbook; (2) validating the textbook; (3) textbook trial in elementary school; (4) Evaluating the textbook; (5) producing the textbook. Textbook as the research output is expected to provide a new sight of Gorontalo language learning for both teachers and students by adjusting EYL learning strategy to sustain Gorontalo culture.

Keywords: Gorontalo language, textbook, English for Young Learner, learning strategy.

\section{Introduction}

Local content is a school-based curricular program that is constituted in article 2 paragraph 1 of the Regulation of the Ministry of Education and Culture No.79 of 2014 regarding the 2013 Curriculum (Kurikulum 2013). According to the regulation, the local content subject is defined as a taught subject about the capacity and characteristics of an area. This subject equips students with an in-depth understanding of such concepts. In addition, the subject aims at preserving the regional identity to cope with the negative impacts of globalization.

The local language is among the taught subject in the local content subject to preserve the language from being endangered. The province of Gorontalois currently promoting the use of Gorontalo language as the speaker of this language is decreasing, this is especially in the urban area. The speakers are mostly elderly, only a few teenagers and children are able to speak using Gorontalo language. People speak using Malay-Manado dialect in daily life as the dialect turns to be a lingua franca for people in Gorontalo in both formal and non-formal situation. On top of that, the elementary students in the province of Gorontalo seem to master the English language faster than learning their local language that also serves as their mother tongue. This results in a situation where teenagers and children consider their local language as a foreign language. Solutions to the problems are urgently required to preserve the use of Gorontalo language and prevent the language from the verge of extinction.

Among the efforts of the government of the province of Gorontalo to preserve the local language is by designing a syllabus of the local content subject of Gorontalo language for elementary schools. The principle of the lesson in the subject is teaching the local wisdom of the area, comprising the customs, cultural heritage, traditional food and art. This subject also prepares the students to be able to use Gorontalo language in communication. However, the attempts by the government in preserving the language are not that wellimplemented. One of the issues is the unavailability of textbooks and teaching materials of the local content subject 
in some schools. Each school needs to design its own lessons based on the guideline that the school has. As a result, the subject does not sync with the test designed by the teachers in MGMP (Musyawarah Guru Mata Pelajaranor Teacher's Discussion Forum) of elementary school teachers, specifically those who teach the local content subject.

Some research has been conducted to help the government to preserve Gorontalo language, the most recent study concerning this issue is by Husain et al. (2017). This research designs a syllabus for the local content subject focusing on the teaching of Gorontalo language for grade IV elementary school students. The syllabus adapts the EYL (English for young learners) learning strategy. The data analysis employed the ADDIE method consisting of three steps, i.e. analysis, design, and development. This study by Husain et al. undergoes four processes of research, starting from identifying the instructional media, designing the syllabus, validating the syllabus and finally, the fixed syllabus was developed. Despite this, the research does not cover the designing of a textbook for the Gorontalo language subject. To further advance the result, Husain et al. attempt to proceed to the designing of the textbook by referring to the syllabus output from the previous study. This textbook offers a solution to the problems of the local content teachers in all elementary schools in the city of Gorontalo and brings an EYL-based local content subject learning.

\subsection{The Urgency of Local Content Curriculum in Children's Education}

Regulations are established to control the social life of humans, social entities, to conceptualizeapeaceful society. Custom and tradition are among the regulations functioning as social control. These aspects are among the outcome of a culture of a community that contributes to overcoming several issues regarding the elements of culture. Passing down the cultural value from generation to generation is a process of the development of culture (Sumantri, as cited in Mansur, 2012). The regeneration of culture is undergone by effective children's education, i.e. comprehending the customs and the environment. Mansur (2012) proposes that introducing the principles of the local content subject, such as natural and social environment from the point of view of certain culture to students is central to preparing the students to fulfill their needs further. The implementation of the local content curriculum requires the teacher's capabilities to design the curriculum. It involves the ability to design, implement and evaluate the curriculum that improves the student's life skill at the school-based level (Basari, 2014). Nurdin and Usman (as cited in Mansur, 2012) categorize the objectives of the local content subject into two, direct and indirect objective. The direct objective is when the outcome is achieved immediately, while the indirectobjective is a long-term goal; and it is the impact of the direct objective. These classifications are explained as follows:

a. Direct Objective

1. The learning materials are understandable for students; they can comprehend it easily

2. Preferring to utilize the local resources in learning

3. Students are able to apply the knowledge and skills from learning to solve real-life problems 


\section{$\triangle$ Macrothink}

4. Students are familiar to the natural, social as well as cultural environment of their region.

b. Indirect Objective

1. Improving the students' insight into their region or area

2. The students are expected to assist their parents and their selves in fulfilling their needs.

Considering the above discussion, Mansur (2012) emphasizes the urgency to implement the local content curriculum to help the students' learning by independent observation, research and learning by utilizing the environment.

\subsection{Designing the Local Content Textbook}

The regulation of the Ministry of National Education No. 22 of 2006 considering the Content Standard states that the School-Based curriculum, in addition to involving the basic subjects taught, also regulate the local content subject that should be implemented in all educational level. The local content subject must embed the characteristic of local culture, local wisdom, and discussing the issue of social and environment (Depdiknas, 2004, 2006, 2007). After the curriculum has been changed to the 2013 Curriculum (Kurikulum2013), the previous regulation has been revised to the Regulation of the Ministry of Education and Culture Number 79 of 2, article 2, paragraph 1 that defines the local content subject as a taught subject about the capacity and local characteristics of an area. This subject equips students with an in-depth understanding regarding the excellence and local wisdom that their area has (DIKBUD, 2014). The objective of this subject aims at developing the students' skills based on the potential and the local wisdom of their region. Some studies have been attempted to explore the development of the instructional media for the local content subject. Among the studies is by Muktadir and Agustrianto (2014) that attempt to design an instructional media that integrates the local wisdom of the province of Bengkulu, i.e. the folklore of the region written in Rejang language (ka, ga, nga). Their research employed the R\&D method by Borg and Gall and integrated the approach of language teaching by Jolly, Balitoand Richard. The result shows that the integration of the folklore functions to promote character education. Despite this, the research is yet to examine the characters of the stories; some other folklores from the region are not covered in the instructional media as well. Faisal and Sulkipani (2016) carried out similar research employing the same methods to develop instructional media for the citizenship subject that integrates the local wisdom of the people in South Sumatera. This research explores the contribution of the instructional media to the university students. The result reveals that the instructional media is of valid and holds the potential to the improvement of the students' learning. The students' learning outcome is increased from 6.86 to 7.73 after the implementation of the media. This suggests that the developed media can be widely used by other teachers. Another research by Ramdani et al. (2016) also attempts to design similar instructional media by integrating comic strips explaining the culture of Banyumasan. The advantages of the use of comic are enriching the students' vocabulary pools, assisting the students to comprehend the abstract concept, promoting the students' reading interest, and improving the effectiveness of teaching and learning. This research used R\&D method with a 
4-D model by Thiagarajan, SemmelandSemmel that has been modified into three steps, i.e. defining, designing, and developing. It is revealed that the developed instructional media contributes to the students' achievement, confirming its applicability in learning.

\subsection{English for Young Learners (EYL) Learning Strategy}

English for Young Learners (EYL) learning is a process of learning English for children aged 6-12 years or those who are at the elementary school level. In EYL learning, students are taught teaching lessons using appropriate learning strategies for the age of elementary school children. The lessons should be fun, easy to understand and presented in an interesting way. According to Piaget (cited in Suyanto, 2007: 15), the way children think is developed through direct involvement with objects and the environment around them. In other words, the developmental period occurs when children are at the elementary school level so that teachers must be able to work with their students, so that they can find out the changes in the cognitive development of these children.

There are several learning strategies used in the EYL teaching process for elementary school students, namely; pairing activities, group discussions, cooperative learning, modeling and demonstrating, concept mapping, outdoor activities, drawing and coloring, listening and repeating, role-playing, and the like.

In the process of learning Gorontalo language as a Local Content subject, Gorontalo cultural wisdom values will be taught more easily and interestingly because the teacher uses or develops learning strategies based on the learning objectives. For example, for listening skills, the teacher will use the EYL Listening and Repeating strategy where the teacher will pronounce the words of Gorontalo language to students, so that they can practice how the words are pronounced and the teacher can guide them to practice saying the words. Another way is by listening to children's songs since you can also practice listening to how the words of Gorontalo language are used through tones that are easily memorized by early childhood. In this EYL strategy, the teacher can use a recorder (recording) media or tape script (writing). For speaking language skill, the teacher can use modeling and demonstration strategies, for example in instructional dialogues about typical foods of Gorontalo. It also uses the EYL modeling strategy. In this strategy, the teacher becomes a model for students in pronouncing the words or sentences of Gorontalo language. For instance, in teaching songs, alongside students can listen, they also have to be able to sing the song in Gorontalo language after being given modeling by the teacher first. Further, in reading skill (Reading), the teacher can apply the EYL role-play strategy in which he can teach students to understand the contents of the reading, such as Gorontalo folklore. By reading the contents of the Gorontalo folklore, they will ask students to do role play strategies where the teacher will ask students to play roles in accordance with the characters in the folklore. In the last language skill, writing, the EYL strategy that can be applied by the teacher is mind mapping. In this strategy, students are expected to be able to write whether in the form of words or sentences or to compose several sentences in a paragraph in Gorontalo language. To facilitate elementary school students, the teacher should be able to provide an easy-to-understand direction in order that students can give their ideas in writing easily by using the EYL mind mapping strategy. Therefore, the 
teacher directs students to map things or story ideas that they will write or arrange started from the beginning to the end of their writing.

In the EYL learning strategy, there are also numerous games that elementary school children prefer to do attractive activities rather than just learning in the static form in the classroom that makes them surfeited, bored, and depressed in learning the language. Suyanto $(1977 ; 17)$ stated that children in an early age tend to like to be imagined and active. They love to learn through games in order that they will be more motivated.

\subsection{Development of the Local Content Textbook based on the Learning Strategy of English for Young Learners}

Bay et al. (2018) in their research explore the use of English for Young Learners (EYL) learning strategy in developing a syllabus of the local content subject Gorontalo language for elementary school students (age 6 to 12). The principle in this learning model is to employ appropriate learning strategies for elementary students, i.e., using understandable teaching resources as well as attractive and fun learning experiences. According to Piaget (as cited in Suyanto, 2007, p.15), children's thinking capacity develops through activities that engage children with the environment. The teachers are demanded to collaborate with their students to recognize the students' development. There are a number of strategies in the EYL learning for elementary students, i.e., pair activities, group discussions, cooperative learning, modeling and demonstrating, mind mapping, outdoor activities, drawing and coloring, listen and repeat, and role play. The research by Bay et al. employed the R\&D method using the ADDIE approach by Dick and Carey (1996) comprising five stages, i.e. analysis, designing, development, implementation and evaluation. The development of the syllabus was done in three steps, i.e. analysis, design, and development. The product of this research is a syllabus for the local content subject that implements the use of audio-visual media to motivate the students in learning.

\section{Research Methodology}

\subsection{Method}

This research is carried out by applying the research and development (R\&D) method; it aims at resulting a product as well as to assess its effectiveness (Sugiono, 2014: 297).

\subsubsection{Stages in Research and Development}

The objective of this research is to design a textbook for the local content subject; this is done in some steps, such as creating the textbook, conduct a large-scale trial to test the textbook in learning, re-validating the lacks of the textbook, and; creating the final textbook. The detail is provided in the following table:

\subsubsection{Site and Subject of Research}

This study was conducted in elementary school, SD Lab, in the city of Gorontalo. It involved all 22 grade IV students from the school. 


\section{Macrothink}

\subsection{Data Collection}

The data were gathered through distributing questionnaires and conducting an informal interview to investigate the needs of both teachers and learners. The questionnaire aims at investigating aspects, such as (1) textbooks used, (2) teaching methods in developing the teaching materials, (3) major concerns regarding the use of the textbooks, and (5) suggestions and inputs from teachers and students regarding the textbooks of Gorontalo language subject. The teachers refer to those who are responsible for teaching the local content subject. Furthermore, an interview with the school principal was also done to gain data regarding his or her expectation as the decision-maker. Preceding the step was the analysis of the teaching materials previously used by employing the Little John framework (as cited in Tomlinson, 2007:190-200). This framework is comprised of two main aspects: publication and design. Publication refers to the physical dimension of the materials while design resembles abstract things: the concept or the essences of the teaching resources. Designing the teaching materials was conducted once all the data have been collected.

\subsection{Data Analysis}

This research employed the ADDIE model developed by Dick and Carey (1996) as the data analysis method. It comprised of five stages, namely analysis, design, development, implementation and evaluation. The analysis, design and development were carried out in the first year of the research and the implementation and evaluation were in the second year.

The steps in the first year of the research are explained as follows:

\section{a. Analysis}

This step encompasses the identification of problems, analysis of learning instruments and the needs of students and teachers, the teaching method(s) and reviewing related literature.

b. Design

A systematicprocess has been attempted in this step; it involves setting the learning goals, designing teaching and learning activities, constructing learning instruments, materials and the evaluation of learning.

\section{c. Development}

The instructional media have been created in this step. It comprises new elements along with the new lesson plan, the media, and the lesson.

The steps in the second year of the research are explained as follows:

d. Implementation

The textbook of the local content subject Gorontalo language has been created in this step. A small-scale test involving elementary students as the subject was carried out to examine the use of the textbook.

e. Evaluation 
Within this step was the evaluation of the EYL-based textbook. This was by observing the class and conducting an interview with teachers.

\section{Results and Discussion}

The objective of this two-year research is to create a textbook for the local content subject that integrates the EYL learning strategy based on the syllabus designed in the first year of this research. It is expected that the product of this research can serve as the guideline for the elementary school teachers, especially for those who teach the local content subject. This study employed the ADDIE data analysis model which comprised of three steps, i.e., analysis, design, and development (Dick and Carrey, 1996). There are five stages in conducting this research: (1) Designing the textbook; (2) validating the textbook; (3) small-scale trial; (4) Evaluating the instructional media, and; (5) Creating the final product of the textbook.

\subsection{Designing the Textbook}

This process began by collecting the data for the instructional design especially some illustrations and pictures for the lesson and content within the textbook. These pictures were from personal source and the internet; these were selected based on the needs of the textbook content. Following this step was the designing of the textbook by referring to the syllabus from the result of the research in the first year; this spent 3 months starting from May to July 2018. The contents encompass the culture of Gorontalo, such as the traditional songs HulondhaloLipuu, Moleleyangi and Biteya, traditional dances Dana-Dana and Saronde, traditional musical instruments Polopalo, Maruwasi and Suling, and traditional games Tengge-tengge, TenggediandAawuta.

The textbook entitled "Mari BelajarBahasaGorontalo" (Let's Learn Gorontalo Language) consists of 4 chapters. These chapters discuss traditional songs (chapter 1), traditional music instrument (chapter 2), traditional dances (chapter 3), and traditional games (chapter 4). Each chapter has three to five activities explained as follows:

\section{Chapter 1 Traditional Songs}

\section{a. Lesson 1 Greetings}

This lesson discusses the greetings in Gorontalo language, e.g. how to greet people and respond to it, asking someone's name and their condition and answering it, as well as asking students' insight regarding the traditional songs of Gorontalo. The activities within this lesson cover listening, pronunciation, reading and sing a song.

\section{b. Lesson 2 Hulonthalo}

Within this lesson is a topic discussing the environment of Gorontalo through a song, i.e.HulonthaloLipu'u. The activities include reading and pronunciation, listening, writing, matching pictures to a word and completing a song lyric.

c. Lesson 3 Occupation

The lesson in this unit introduces the students some occupations. The students engage in some 


\section{Macrothink}

International Journal of Learning and Development

activities, such as see-and-pronounce, listen-and-say, and matching pictures.

d. Lesson 4 Biteya

This lesson discusses the song Biteya. It equips the students with the vocabularies within the song lyric. The activities cover listening, reading, pronunciation, sing a song, and quiz.

\section{e. Lesson 5 Moleleyangi}

This lesson focuses on the map of Sulawesi Island, understanding the activities and the song of Moleleyangi, as well as completing and the song lyric.The activities include see-and-point, hear-and-say, reading, pronunciation, sing a song, and fill in the blank.

Chapter 2 Traditional Musical Instruments

\section{a. Lesson 1 Time}

This lesson focuses on teaching time and related expression through playing a traditional musical instrument. Some activities are listening, pronunciation and speaking, matching the picture, read-and-do, group activities, and completing sentences.

b. Lesson 2 Greetings

The students learn some greeting expressions in Gorontalo language through playing musical instruments. Some activities are listening, pronunciation and speaking, matching the picture, read-and-do, group activities, and writing.

\section{c. Lesson 3 Traditional Musical Instruments}

The students focus on learning kinds of musical instrument and how to play it. Some activities are listening, pronunciation and speaking, matching the picture, read-and-do, and group activities.

d. Lesson 4 Playing Traditional Musical Instruments

This lesson emphasizes the techniques in playing traditional musical instruments. The activities include observation, performance, completing sentences, and playing games.

Chapter 3 Traditional Dances

a. Lesson 1 Colors and Numbers

This lesson introduces some vocabularies describing colors and numbers in Gorontalo language. It also teaches the students the colors used in the costume of Dana-Dana dance. The students are engaged in some activities, such as listening, pronunciation, practicing Dana-Dana dance, and sentence completing.

\section{b. Lesson 2 My Face}

The students learn some vocabularies regarding the parts of the human face in Gorontalo language. The activities comprise listening, pronunciation, total physical response activities, reading and re-writing. 
c. Lesson 3 My Body

This lesson focuses on teaching vocabularies about parts of the body in Gorontalo language. The activities comprise listening, pronunciation, and matching pictures with the word.

d. Lesson 4 Dance

This lesson provides the students a brief history of Saronde and Dana-Dana through watching videos. The students also learn to perform the dances.

Chapter 4 Traditional Games

a. Lesson 1 Direction

This lesson introduces the students some vocabularies of showing directions in Gorontalo language. Some activities in this lesson are listening, pronunciation and speaking, matching picture, read-and-do, group activities, and writing.

b. Lesson 2 Playing Tengge - tengge

The students continue to learn some traditional games of Gorontalo through activities, such as listening, quiz, pronunciation, writing, and reading.

c. Lesson 3 Having Fun by Playing Tenggedi

The students learn how to create a sentence describing the traditional games of Gorontalo. They also participate in a quiz and riddles about the traditional games. Some activities are listening, pronunciation and speaking, matching picture, treasure hunt, and writing.

d. Lesson 4 Playing Let's Play Together

This lesson provides the students with videos about the traditional games of Gorontalo. Guided by a teacher, the students further play some of the games. The activities include observation and playing games.

The activities in the textbook adapt some of the learning strategies of EYL, e.g. listen and repeat, listen and practice, let's play game, let's sing, matching, watching videos, pronunciation, and role play. This offers a new, unique approach that distinguishes this textbook with past books. The students are encouraged to participate actively in the activities that are mostly applied in EYL learning. Furthermore, the layout and contents of the textbook, such as the font and illustrations are designed to attract the students' learning interest and to motivate them in learning Gorontalo language.

\subsection{Validation of Textbook}

A focus group discussion (FGD) was held on 29 August 2018 to validate the textbook for the local content subject. Four experts of Gorontalo language, curriculum and EYL, as well as five elementary school teachers who teach the local content subject were involved in this discussion.

The following are several suggestions regarding the textbook: 
1. The use of vocabularies of Gorontalo language does not fit to the context of the sentence. This is mostly in the complex element of the language, such as the use of wa'uandwatiyain terms of the politeness, consistence in writing some words, such as Pontiand Poonti, Hulondalo, Hulonthalo or Hulontalo, as well as the use of the third person te- and $t i$ - that does not match to the illustrations.

2. The use of the size of the font is lack of consistency.

3. The font for the lesson should be colored black except for indicating the title and chapter of the book.

4. Some of the illustration characters should be named to ease the students to learn Gorontalo language, especially in indicating the subject of a sentence or utterance.

5. Some of the illustrations should depict the meaning of the vocabularies. For example, using a photo of a tan-skinned man is appropriate to depict the word Paita(uncle with dark-colored skin).

6. Some sub-topics should fit the context of the general theme.

7. Instructions in Indonesia language must be integrated into every lesson in the textbook.

Following the FGD is a discussion among the writer team to consider the above correction in revising the final textbook. This step took 10 days, starting from 1-10 September 2018. The result of the discussion found some issues in the use of vocabularies that do not match the context. Furthermore, discussing the meaning of the vocabularies, especially describing parts of a body, with the expert in Gorontalo language is essential. This also aims to design the instruction for the classroom activities.

\subsection{Small-scale Trial of the Local Content Textbook}

A small-scale trial was conducted to assess the use of the textbook product in the classroom. It also aims at observing the respond of the teachers and students regarding the textbook. This test was conducted at the elementary school SD Lab Gorontalo City; all grade IV students were selected as the participant. Other than the accessible location of the school, the reason for selecting the school is well-known for its quality human resources, specifically the local content teachers in the city center of Gorontalo. The result of the pre-observation with the teachers reveals that most of the students are unable to speak in Gorontalo language. This also serves as the grounding of selecting the school as the site for the trial.

The trial was conducted for two days, starting from 12-13 September 2018 during the 2-hour local content class each day. The classroom activities were recorded in a video to observe the communication and interaction between the teacher and the students. In addition, the teachers also involve in an informal interview to find out the information regarding classroom learning. The video reveals an active classroom based on the interaction between the teacher and the students. The use of the textbook promotes the teacher's performance and enthusiasm in teaching as the lesson and activities within the textbook boost the students' participation in 
learning. In addition, the textbook boosts the teacher's creativity and initiative in teaching. This is reflected in the way the teacher improves the performance in teaching. The activities based on the EYL-learning from the textbook inspire the teacher in teaching. This improves the students' engagement in every activity in the class. For example, the students are able to sing a song in Gorontalo language. Another interesting issue is when the students practice a short conversation talking about occupations in Gorontalo language. Some students are able to improvise in creating the dialogue for the conversation. Such a breakthrough is new to the implementation of the designed textbook.

An informal interview with the local content teacher was due. It aims at finding out the responses regarding the impact of using the textbook in the class. It is revealed that the textbook motivates the teacher and the students in every EYL learning strategies implemented in the learning. As a result, the students are more eager to learn Gorontalo language as they find the learning activities new to the local content class. The activities in the textbook adapt some of the learning strategies of EYL, e.g. listen and repeat, listen and practice, let's play the game, let's sing, matching, watching videos, pronunciation, and role play. The teacher clarifies that the teaching and learning of the local content subject, including the use of the textbook and the teaching method, seems monotonous. This explains the reason why the teacher needs a breakthrough in the teaching and learning of the local content subject. One of the innovation is the EYL-based textbook for the local content subject.

The result of the questionnaire regarding the textbook product shows a positiveresponse from the teacher as the book offers an innovative learning strategy (the EYL learning strategy) in teaching Gorontalo language. There are 13 questions within the questionnaire. The teacher enthusiastically points out that the EYL-based textbook is a solution that the teachers and students need the most due to its lesson. Most of the students find that the lessons within the textbook are easy to understand by which it drives them to comprehend and attain the learning objective. In addition, the look, images, font colors, and animation within the textbook are able to draw the students' interest in learning. This promotes the students' engagement in every activity in the class. The practices of language skills, i.e. speaking, writing, reading, and listening, and other components of language learning (such as vocabulary learning) are effectively designed. At the end of the questionnaire, the teacher expects that the EYL-based textbook for the local content subject can be distributed to other teachers, especially in the city of Gorontalo as it significantly contributes to the teaching and learning of the local content subject, specifically in Gorontalo language class.

\subsection{Textbook Evaluation}

An evaluation of the textbook was done for several days after the validation of the textbook at the elementary school SD Lab, Gorontalo City. It aims to minimize some drawbacks of the textbook. The textbook will be corrected again if some components, especially in diction and the spelling of some vocabularies are still not correct. This process involves a Gorontalo language expert because it is quite difficult and requires precision. After the editing process, the textbook is ready to be published during the second FGD. The discussion forum involved some stakeholders, such as the Department of Education and Sports Affair of Gorontalo City, 
the Language Development and Fostering Board of Gorontalo City, experts in culture (specifically in Gorontalo language), as well as teachers of the local content subjects and university students.

\subsection{Designing the EYL-Based Local Content Textbook}

The EYL-based textbook that will be published entitles "Mari BelajarBahasaGorontalo" (Let's Learn Gorontalo Language). The syllabus is for the fourth grade of elementary students since they are in the upper-classlevel. They are mentally well-prepared to learn a foreign language (Suyanto, 2007, p.18-19). However, it does not mean that the upper-class students, i.e. grade 5 and 6 are unable to use the textbook in learning. The activities within the textbook adapt the learning strategy of EYL that offer a unique approach to the learning of Gorontalo language.

One of the attempts in the preliminary publication is the FGD 2 by involving some stakeholders, i.e. the Department of Education and Sports Affair of Gorontalo City, the Language Development and Fostering Board of Gorontalo City, and experts in culture (specifically in Gorontalo language). Several teachers of the local content subject and some university students also participated in this forum. The FGD took place during the fourth week of September 2018.

Re-evaluating the textbook will be conducted after the FGD if necessary; this depends on whether or not there are corrections to be made during the FGD 2. The manuscript is sent to the publisher if the final revision has been made. As many as 50 textbooks will be distributed to some elementary schools in Gorontalo City as well as the Department of National Education in the province. It is expected that the textbook is of significant contribution to the teachers in teaching Gorontalo language and is able to motivate the students in understanding their local language.

\section{Conclusion}

This study aims to produce teaching materials in the form of the Local Content textbook entitled "Let's Learn Gorontalo Language" by adopting an English learning strategy for children (EYL) by focusing on the material about local wisdom or Gorontalo culture. This research was carried out through 5 stages, including: (1) preparation of teaching material products; (2) validation; (3) Trial of small-scale teaching materials; (4) Evaluation of teaching materials; and (5) MULOK teaching materials.

The stages of preparing teaching materials begin with collecting data and images for teaching material that took for about 3 months, i.e., May, June and July 2018. The content of the material includes several Gorontalo cultures, such as traditional songs, traditional dances, traditional musical instruments, and traditional typical games of Gorontalo region. This textbook consists of four chapters, and each of them comprises four to six lessons. After being compiled, there was a stage 1 FGD involving several speakers in the curriculum, EYL, and Gorontalo languages as well as several Local Content subject teachers. Corrections or suggestions given during the implementation of Stage 1 of the FGD are very important for the perfection of this textbook. After being revised, this book was tested at 4th-grade students of 


\section{Macrothink}

International Journal of Learning and Development

ISSN 2164-4063 2019, Vol. 9, No. 1

Elementary School LAB Gorontalo to see the learning situation when this textbook was used and found out the teacher's response to this textbook through written interviews. Internal evaluation is conducted based on the input from the teacher after the small-scale trial and revised by Gorontalo language speakers. After that, the initial publication was conducted by holding a Stage 2 FGD and involving relevant parties and stakeholders, including Gorontalo provincial language hall, the Department of Education in Gorontalo, Gorontalo language observers, Local Content teachers and students. The corrections and inputs obtained in the Stage 2 FGD were followed up in the research team's internal discussions. This textbook will be printed out around 50 copies and distributed to several schools in Gorontalo and the Department of Education of Gorontalo. It is expected that this textbook can provide new nuances in the process of learning English to improve students' motivation to learn their own local language.

\section{References}

Abdussamad, K., Dali, T., Tuloli, N., Dujo, D., Musa , T. A., Kasim, M. M., ... danWahidji, H., (1985).Empat Aspek Adat Daerah Gorontalo [The Four Aspects of Gorontalo Local Custom], PT. Aksara Indira harapan, Jakarta.

Agung, Leo danWidyastuti, Endang.Pengembangan Model Pembelajaran Muatan Lokal Di Sekolah Menengah Berbasis Keunggulan Budaya Seni Batik Klasik Surakarta Sebagai Upaya Pelestarian Warisan Budayadan Menumbuhkan Jiwa Kewirausahaan. Retrieved 16 October, 2018, from https://digilib.uns.ac.id/dokumen/download/264700/MjY0NzAw

Agustin, M. (2011). PermasalahanBelajardanInovasiPembelajaran. PT. RefikaAditama

Aundriani, L., \& Saeful, Z. (2012). Membuat Anak Rajin Belajar itu Gampang. Visi media

Basari, A. (2014.) Penguatan Kurikulum Muatan Local dalam Pembelajaran di Sekolah Dasar. Seminar Nasional.

Bay, Indri Wirahmi Husain, Nurlailadan Mamu, Rahmawaty. (2018). Developing Local Content Syllabus for Elementary School Based on the English for Young Learners Learning Strategy to Maintain Gorontalo Cultures. The Asian EFL Journal January, 20(1).

Depdiknas. (2004). Peningkatan Kualitas Pembelajaran. Jakarta: Depdiknas. Retrieved 16 October, 2018, from https://goenable.wordpress.com/tag/depdiknas-2004/

Depdiknas. (2006). Kurikulum Tingkat Satuan Pendidikan. Jakarta: Depdiknas. Retrieved 16 October, 2018,from repository.upi.edu/5538/10/S_PGSD_1007994_Bibliography.pdf

Dick, W., \& Carey, L. (1978). The systematic Design of Instruction. Retrieved April 18, 2015, from http://en.wikipedia.org/wiki/instructional_design\#Dick

Diran, Z. (2009). Keberadaan Bahan Ajar dan Pembelajaranny. Retrieved from https://zulkarnainidiran.wordpress.com/2009/06/28/131/

Djibran, M. (2015). Pengembangan Bahan Ajar Cerita Bergambar Berbasis Kearifan Lokal Pada Peserta Didik Kelas 1 SD Al Huda Kota Gorontalo. Thesis. Universitas Negeri 
Gorontalo: Gorontalo.

Faisal, Emil El dan Sulkipani. (2016). Pengembangan bahan ajar berbasis Muatan local p adamatakuliah Pendidikan Kewarganegaraan. Jurnal Civics., 13(2). Retrieved October 16, 2018, https://journal.uny.ac.id/index.php/civics/article/view/12721

Hardan, A. A. (2013). Language Learning Strategies: A general overview. $4^{\text {th }}$ international conference on new horizons in education, Procedia-social and behavioral sciences, 106 (2013) 1712-1726. Elsevier. Retrieved 18 October, 2018, from sciencedirect.com

Husain, N. Bay, I. W., \& Mamu, R. (2017). Ajar (MULOK) Sekolah Dasar Berbasis Strategi Pembelajaran "English for Young Learners" untuk Mempertahankan Nilai-nilai Kearifan Lokal Gorotalo. Laporan Penelitian. Universitas Negeri Gorontalo: Gorontalo

James, D. (1997). Folklor Indonesia. Jakarta: Grafiti.

Kirsch, C. (2011). "Developing children's language learner strategies at primary school" Retrieved $16 \quad$ October, 2018, from https://research.gold.ac.uk/3635/2/Educ3-13MLissueArticle2Kirsch22_July.pdf

Mansur, N. (2012). Urgensi Kurikulum Muatan Lokal dalam Pendidikan. Jurnal Ilmiah DIDAKTIKA, XIII (I), 68-79.

Muktadir, A., \& Agustriant. (2014). Pengembangan Model Mata Pelajaran Muatan Lokal Berbasis Kearifan Lokal Untuk Meningkatkan Karakter di Sekolah Dasar Provinsi Bengkulu. Jurnal Pendidikan karakter UNY, 3. Retrieved 16 October, 2018, from https://journal.uny.ac.id/index.php/jpka/article/view/5636

Mulyanto A., Muslimin Latief, M., \& Rohandi, M. (2014). Pengembangan Aplikasi Repository Digital Budaya Gorontalo dalam Upaya Melestarikan Budaya Lokal. Laporan Penelitian: Gorontalo.

Pateda, L. (2011). Pengajaran Bahasa Gorontalo Sebagai Muatan Lokal di SD Kota Gorontalo. Jurnal Bahasa, Sastradan Budaya. 1(1). Retrieved 12 April, 2015, from http://issuu.com/jurnal.bahasa/docs/9._lamsike_pateda_ok1/1

PERMENDIKBUD NO. 79. (2014). Retrieved 16 October, 2018, from https://jdih.surabaya.go.id/pdfdoc/permen_7.pdf

Ramadani, Citra Ayu. Irianto, Sony danYuwono, Pratik Hari. (2016). Pengembangan Bahan Ajar Muatan Lokal Budaya Banyumasan Menggunakan Media Komik Di Kelas IV Sekolah Dasar. Thesis. Universitas Muhammadiyah Purwokerto.

Setyarini, S. (2010). "Puppet Show": Inovasi Metode Pengajaran Bahasa Inggris dalam Upaya Meningkatkan Kemampuan Berbicara Siswa SEKOLAH DASAR. Jurnal Penelitian Pendidikan, 11(1), April 2010.

Sugiono. (2014). Metode Penelitian Kuantitatif Kualitatifdan R\&D. Alfabeta: Bandung.

Suyanto, \& Kasihani, K. E. (2007). English for Young learners. melejitkan Potensi Anak 


\section{Macrothink}

International Journal of Learning and Development

Melalui English Class yang Fun, Asyik, dan Menarik. Bumi Aksara: Jakarta.

Thomson, Natascha. "Language Teaching Strategies and Techniques Used to SupportStudents Learning in a Language other than Their Mother Tounge”. Retrieved 16 October, 2018, from https://www.ibo.org/contentassets/4ccc99665bc04f3686957ee197c13855/thompson_execsum _8-29-12.pdf

Tim Perumus Kerjasama Pemda Kabupaten Gorontalo, Forum Pengkajian Islam al-Kautsar Gorontalo dan Tim Akademisi Gorontalo. (2008). Pohutu Aadati Lo Huondalo-Tata Upacara Adat Gorontalo. Pemda Kabupaten Gorontalo.

Tomlinson, B. (2007). Developing Materials for Language Teaching. Continuum: London.

\section{Copyright Disclaimer}

Copyright for this article is retained by the author(s), with first publication rights granted to the journal.

This is an open-access article distributed under the terms and conditions of the Creative Commons Attribution license (http://creativecommons.org/licenses/by/4.0/). 